\title{
Pozzolanic Potential and Mechanical Performance of Wheat Straw Ash Incorporated Sustainable Concrete
}

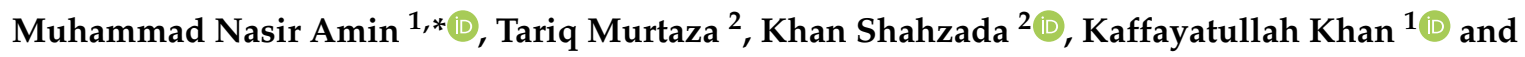 \\ Muhammad Adil ${ }^{2}$ \\ 1 Department of Civil and Environmental Engineering, College of Engineering, King Faisal University (KFU), \\ P.O. Box 380, Al-Hofuf, Al-Ahsa 31982, Saudi Arabia; kkhan@kfu.edu.sa \\ 2 Department of Civil Engineering, University of Engineering and Technology (UET), \\ Peshawar 25120, Pakistan; tariq_891@yahoo.com (T.M.); khanshahzada@uetpeshawar.edu.pk (K.S.); \\ adil@uetpeshawar.edu.pk (M.A.) \\ * Correspondence: mgadir@kfu.edu.sa; Tel.: +966-13-589-5431; Fax: +966-13-581-7068
}

Received: 11 December 2018; Accepted: 12 January 2019; Published: 19 January 2019

\begin{abstract}
The pozzolanic potential, mechanical strength, and stress-strain behavior of a locally available wheat straw ash (WSA) as a partial substitute of cement was evaluated in this study. Various samples of a locally available wheat straw were burnt to ashes at three distinct temperatures and characterized through X-ray powder diffraction and energy dispersive X-ray spectroscopy. The WSA obtained from burning at $550{ }^{\circ} \mathrm{C}$ was found highly amorphous and possessed suitable chemical composition to be used as pozzolanic material. The burned WSA was grounded to achieve the desired fineness and mortar cubes and concrete cylinders were cast by substituting $15 \%, 20 \%, 25 \%$, and $30 \%$ cement with it. The strength of mortar and concrete decreased with increasing amounts of WSA except for those containing $15 \%$ WSA, where it slightly increased than the respective control samples at later ages, i.e., 28 and 91 days. Despite reduced strength at high replacements $(20 \%, 25 \%$, and $30 \%)$, the strength activity index values met ASTM C618 requirements for pozzolanic materials. Moreover, the compressive strength of concrete containing 20\% WSA exceeded to that of control concrete at 91 days. The stress-strain relation of concrete containing $15 \%$ to $20 \%$ WSA also showed comparable stiffness and toughness to those of control samples at all ages. Particularly, the concrete containing 15\% WSA showed significant improvement of strength, stiffness, toughness, and ductility at 91 days. Lastly, the results of mechanical strengths and pozzolanic reactivity were successfully validated indirectly by measuring the porosity of mortars and thermo-gravimetric analysis of cement pastes, respectively. Based on current findings and their validation, WSA can be used as a substitute of cement up to $20 \%$ in the production of sustainable normal strength concrete for their application in common domestic building projects.
\end{abstract}

Keywords: pozzolanic potential; wheat straw ash; compressive strength; strength activity index; porosity; thermogravimetric analysis

\section{Introduction}

Concrete is the most widely used man-made material on the earth. For each person worldwide, almost 2.3 cubic yards of concrete is consumed every year [1]. The extensive use of concrete is mainly due to the easily availability of its raw materials, its proven flexibility, superficial mechanical and improved durability properties under severe environmental conditions, low maintenance throughout its life, and so on. Besides the important role that the concrete industry is playing in the development of our society, it is also responsible for the production of $10 \%$ of the industrial carbon dioxide $\left(\mathrm{CO}_{2}\right)$ emission to the environment. Only the production of cement, which is the most important constituent of concrete, is contributing $6 \%$ of the global $\mathrm{CO}_{2}$ emission [2-4]. The global $\mathrm{CO}_{2}$ emission is severely 
affecting the earth's temperature, which causes climatic changes and global warming related issues [5]. In addition to $\mathrm{CO}_{2}$ emission, the cost increment in energy for the production of cement, depletion of natural resources, and enough of a supply of raw materials needed in the manufacturing of cement in a desired quality are other major concerns of most cement producing countries. The construction of new and repaired existing facilities also requires huge amounts of concrete and this demand is even expected to increase with current increasing trends of urbanization. Many researchers around the globe are currently working to reduce its environmental footprint. Trends of using innovative materials with a reduced carbon footprint, high strength, and increased design-life of concrete structures are being developed recently. There is an increasing demand of using lightweight aggregate to produce lightweight concrete for structural application and using fiber reinforcement in mortar and concrete to reduce the size of structural members [6-10].

Among the different technologies, the most effective way to reduce $\mathrm{CO}_{2}$ emission is to minimize the use of clinker by substituting it partially with supplementary cementitious materials [11-14]. Commercially available popular materials such as fly ash, slag, silica fume, calcined clays, and natural pozzolans are already being used for such purposes [15-21]. Recently, the effectiveness of some locally produced wastes such as electric arc furnace slag, lime stone quarry dust, glass waste sludge, and industrial granite sludge as potential cement substitute were studied [22-24]. However, with continuous increasing demand of concrete, there is a dire need to further investigate other potential materials to partially replace cement, which give at least comparable or improved strength and durability properties. In recent years, many researchers have focused on utilizing the different industrial wastes in the production of sustainable cement and concrete.

The production of a huge amount of agricultural waste causes several environmental and landfill related issues. Some of these wastes were used as a source of fuel in different power plants. Dumping their ashes obtained from burning outside in the open fields causes severe environmental and health issues. Therefore, to promote green construction technologies and to reduce the air pollution problems, a huge variety of agro wastes have been introduced to the current construction industry for their potential use as a substitute of cement clinker. In the last few decades, several research studies have been performed on the potential use of agro wastes such as sugarcane bagasse ash and rice husk ash in the construction industry. Due to the presence of a high amount of amorphous silica, many researchers consider these ashes as good pozzolanic materials for the production of sustainable cement and concrete [25-28]. Just like sugarcane and rice, wheat is the largest cereal crop and is one of the primary sources of food for 2.5 billion people worldwide [29]. The global estimated production of wheat from 2016 to 2017 was 750 million tons. Pakistan is also among the largest wheat producing countries in the world. The annual production of wheat in Pakistan was estimated as 26.6 million tons from 2017 to 2018 [30]. According to Pan et al. [31], one $\mathrm{kg}$ of wheat grain produces almost 1.3 to $1.4 \mathrm{~kg}$ of wheat straw. Most of this wheat straw is being used as the main source of food for cattle [32]. However, in some cases, it was found that wheat straws burnt in an open field causes environmental pollution (smog) and related health issues for people living in the area. This includes, for instance, road traffic accidents and respiratory issues in residents, as reported, in some cities of Pakistan and India [33,34].

Recently, many researchers have investigated the role of WSA as a potential supplementary cementitious material in cement and concrete [35-37]. In fact, the pozzolanic efficiency of WSA is mainly dependent on its source, and, hence, the composition of WSA changes from one region to another due to the variation in soil and weather conditions [38]. Other than its origin, the calcination temperature and fineness also play an important role. According to Birick et al. [35], burning wheat straw for $5 \mathrm{~h}$ between $570{ }^{\circ} \mathrm{C}$ and $670{ }^{\circ} \mathrm{C}$ produced the best results and WSA obtained from burning at $670{ }^{\circ} \mathrm{C}$ showed better pozzolanic behavior as compared to the one obtained by burning at $570{ }^{\circ} \mathrm{C}$. Ataie et al. [39] investigated the optimum temperature and burning duration of pretreated WSA and concluded that the burning temperature of $500^{\circ} \mathrm{C}$ for a duration of $12 \mathrm{~h}$ and $600{ }^{\circ} \mathrm{C}$ for $1 \mathrm{~h}$ exhibited improved amorphous silica content as compared to burning WSA at these temperatures for a longer duration. They further showed that the treated WSA yielded more amorphous silica when burned 
at an uncontrolled temperature as compared to a controlled burning, which can help reduce the processing cost at an industrial scale. Recently, Memon et al. [33] examined the effects of different burning temperatures $\left(500,600,700\right.$, and $\left.800^{\circ} \mathrm{C}\right)$ on the pozzolanic behavior of WSA. They showed that increasing the burning temperature beyond $600{ }^{\circ} \mathrm{C}$ resulted in transformation of amorphous silica in to crystalline silica. From different test results, they found that $600{ }^{\circ} \mathrm{C}$ was the optimum burning temperature, which produced WSA with better pozzolanic performance. Many researchers agree that the most favorable temperature for burning WSA lies between $570{ }^{\circ} \mathrm{C}$ to $670{ }^{\circ} \mathrm{C}$ for a duration of $5 \mathrm{~h}$.

After the calcination process, mechanical treatment of WSA significantly increases the fineness and the pozzolanic activity when used as a mineral admixture in mortar and concrete. Qudoos et al. [40] studied the effect of different grinding cycles on the pozzolanic efficiency of WSA. They found that the fineness of WSA increased with increasing grinding duration. Furthermore, finer particles resulted in an increased surface area and enhanced amorphousness with minimum grinding duration of $60 \mathrm{~min}$ in a planetary ball mill. Memon et al. [33] also noted the vital benefits according to which mechanical grinding of WSA for $120 \mathrm{~min}$ increased the Blaine fineness area by almost $48 \%$. The improved fineness of WSA can result in better pozzolanic performance when used as a cement substitute for the production of sustainable concrete.

Few research studies were conducted to investigate the effect of WSA on the mechanical and durability properties of mortar and concrete. Ataie et al. [39] observed a $25 \%$ increase in compressive strength of mortar containing $20 \%$ WSA as a substitute of cement. However, Biricik et al. [41] found compressive strength of mortar containing only $8 \%$ WSA comparable to the control sample after a curing period of 180 days. Despite a slight increase or no increase in compressive strength, both found improved flexural strength at 28 days for $16 \%$ replacement of cement with WSA. Memon et al. [33] observed almost an equal and even better mechanical performance to that of control mortar when mechanically activated WSA partially substituted cement by $20 \%$. Qudoos et al. [40] reported that WSA subjected to extensive mechanical grinding gave better compressive strength at all ages $(7,28$, and 91 days) as compared to control samples with $20 \%$ substitution of cement. Unlike strength, limited research is dedicated to the durability aspect of concrete containing WSA. Concrete containing WSA showed better resistance against a sulphate attack, an alkali-silica reaction, and a freeze-thaw phenomenon [42-44]. This improved durability performance was attributed to enhanced pore and microstructure of WSA-incorporated mortar and concrete [42-44].

Most of the discussed studies have focused on investigating the pozzolanic potential of WSA by performing the basic pozzolanic assessment tests such as chappelli, frattini, and strength activity index (SAI) and so on. Although, few researchers have investigated the influence of burning temperatures and mechanical grinding on pozzolanic potential of WSA. Yet, their optimum percentage replacements and the influence on mechanical properties of concrete with aging (strength, stiffness, ductility, and toughness) is still scarce and needs to be investigated further. Therefore, the current study is mainly focused on assessing the pozzolanic reactivity and mechanical performance of normal strength concrete incorporated with locally available WSA procured from the Khyber Pakhtunkhwa province of Pakistan. Initially, after drying, samples of wheat straw were exposed to three distinct burning temperatures $\left(550{ }^{\circ} \mathrm{C}, 650^{\circ} \mathrm{C}\right.$, and $\left.750{ }^{\circ} \mathrm{C}\right)$ in a rotary kiln for $5 \mathrm{~h}$. The microstructural investigation, such as X-ray powder diffraction (XRD), energy dispersive X-ray (EDX) spectroscopy, and thermo-gravimetric analysis (TGA), were also conducted to study the effect of burning temperature, burning duration, and mechanical activation. The ashes obtained from each burning cycle were characterized using XRD and EDX analyses for optimization. Subsequently, the optimized WSA, which possesses amorphous $\mathrm{SiO}_{2}$ and suitable chemical composition, was subjected to extensive grinding in a ball mill for $2 \mathrm{~h}$ to achieve the desired fineness. Lastly, the influence of different percentages of finely ground WSA $(15 \%, 20 \%, 25 \%$, and $30 \%)$, as a substitute of cement, was evaluated thorough various tests on standard mortar (ASTM C109) and normal strength concrete. The details of test results of development of compressive strength, porosity of mortar, SAI, and stress-strain relation (stiffness and toughness) were presented. At the end, results of TGA on cement pastes were 
also evaluated to validate the pozzolanic reactivity and strength results of WSA-incorporated mortar and concrete.

\section{Materials and Methods}

\subsection{Materials}

\subsubsection{Cement}

Ordinary Portland cement Type-I, in compliance with ASTM standards C150-94, was used in this study to cast mortar cubes and concrete cylinders. The cement was obtained from the Cherat cement factory and details about its physical properties, chemical composition, and compounds are presented in Table 1. The values of cement compounds were calculated from its oxide composition using the Bogue formula as follows $[45,46]$.

$$
\begin{aligned}
& \mathrm{C}_{3} \mathrm{~S}=4.071 \mathrm{CaO}-\left(7.6 \mathrm{SiO}_{2}+6.718 \mathrm{Al}_{2} \mathrm{O}_{3}+1.43 \mathrm{Fe}_{2} \mathrm{O}_{3}+2.852 \mathrm{SO}_{3}\right) \\
& \mathrm{C}_{2} \mathrm{~S}=2.867 \mathrm{SiO}_{2}-0.7544 \mathrm{C}_{3} \mathrm{~S} \\
& \mathrm{C}_{3} \mathrm{~A}=2.56 \mathrm{Al}_{2} \mathrm{O}_{3}-1.69 \mathrm{Fe}_{2} \mathrm{O}_{3} \\
& \mathrm{C}_{4} \mathrm{AF}=3.043 \mathrm{Fe}_{2} \mathrm{O}_{3} .
\end{aligned}
$$

\begin{tabular}{|c|c|}
\hline Item & Physical Properties \\
\hline Specific gravity $\left(\mathrm{g} / \mathrm{cm}^{3}\right)$ & 3.15 \\
\hline Blain fineness $\left(\mathrm{m}^{2} / \mathrm{kg}\right)$ & 301 \\
\hline Initial setting time (minutes) & 145 \\
\hline Final setting time (minutes) & 230 \\
\hline & Chemical Properties (oxides, $\%$ by weight) \\
\hline $\mathrm{SiO}_{2}$ & 21.24 \\
\hline $\mathrm{Al}_{2} \mathrm{O}_{3}$ & 5.56 \\
\hline $\mathrm{Fe}_{2} \mathrm{O}_{3}$ & 3.24 \\
\hline $\mathrm{CaO}$ & 63.53 \\
\hline $\mathrm{MgO}$ & 0.93 \\
\hline $\mathrm{Na}_{2} \mathrm{O}$ & 0.13 \\
\hline $\mathrm{K}_{2} \mathrm{O}$ & 0.62 \\
\hline $\mathrm{SO}_{3}$ & 2.55 \\
\hline Free Lime & 0.55 \\
\hline $\mathrm{IR} *$ & 0.64 \\
\hline \multirow[t]{2}{*}{$\mathrm{LOI} * *$} & 1.24 \\
\hline & Compounds (\%) \\
\hline $\mathrm{C}_{3} \mathrm{~S}$ & 47.95 \\
\hline $\mathrm{C}_{2} \mathrm{~S}$ & 24.72 \\
\hline $\mathrm{C}_{3} \mathrm{~A}$ & 8.76 \\
\hline $\mathrm{C}_{4} \mathrm{AF}$ & 9.86 \\
\hline
\end{tabular}

Table 1. Physical and chemical analysis of Cherat cement.

\subsubsection{Wheat Straw Ash (Burning \& Milling)}

In addition to cement, WSA was used in this study as a partial substitute of cement. It was obtained after burning the local wheat straw at different temperatures of 550,650 , and $750{ }^{\circ} \mathrm{C}$ in a rotary kiln for $5 \mathrm{~h}$ followed by grinding in a ball mill (Figure $1 \mathrm{a}, \mathrm{b}$ ). The wheat straw is a byproduct of wheat crop, which contains a high amount of $\mathrm{SiO}_{2}$ when burnt to ashes. Before burning, it was thoroughly washed to remove any dust or impurities followed by drying in the open air. The purpose of burning wheat straw at different temperatures was to find out the optimum temperature at which its ashes possess the highest amount of $\mathrm{SiO}_{2}$ and an amorphous structure. 

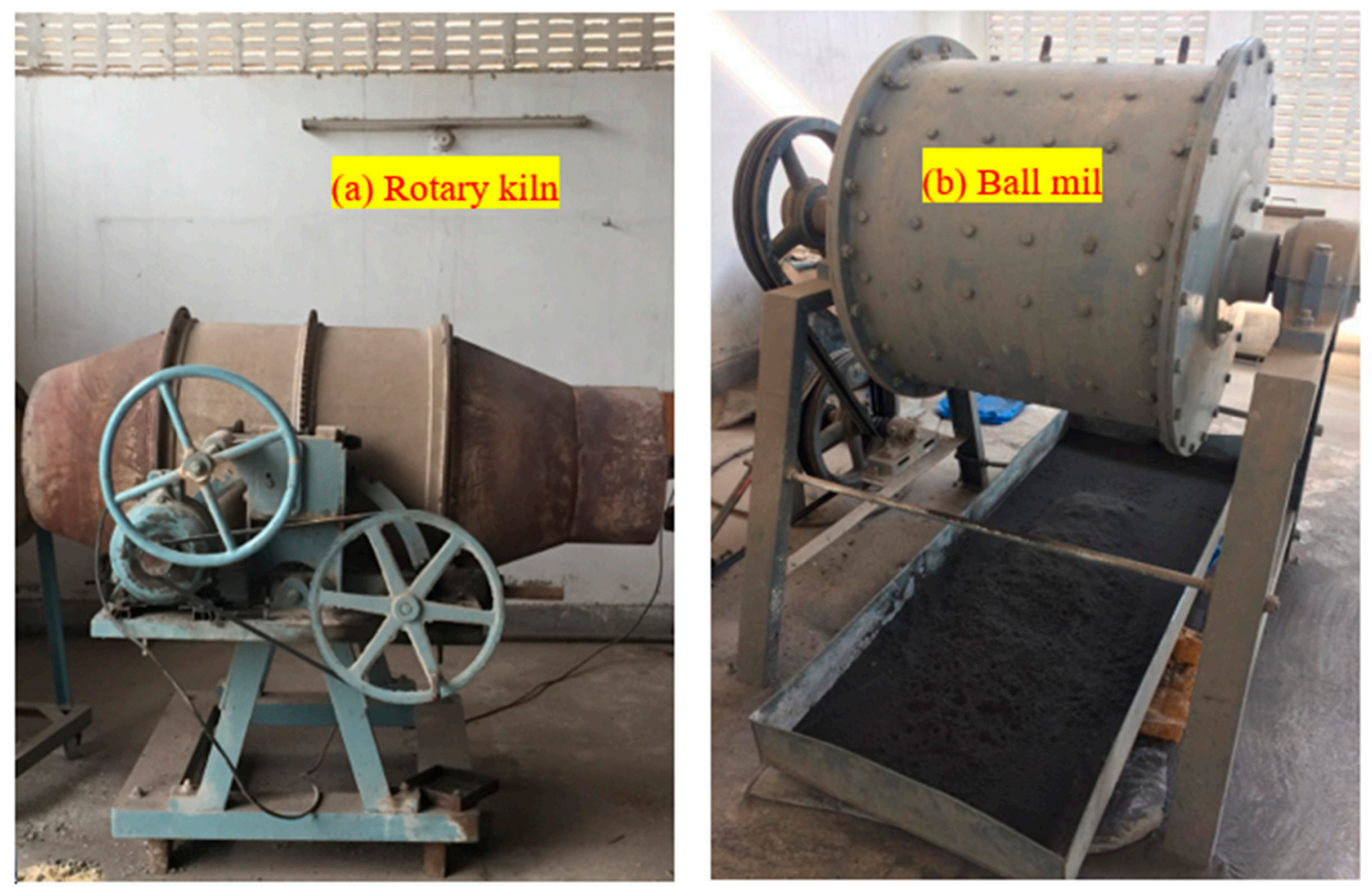

Figure 1. (a) Rotary kiln used in burning wheat straw at different temperatures ranges from 550 to $750{ }^{\circ} \mathrm{C}$ and (b) the ball mill to grind burnt wheat straw ash is collected at the bottom in the photo.

Figure 2 shows the color of wheat straw before and after burning. A slight change in color of burnt ashes from dark to whitish grey was observed with increasing burning temperatures. Changing the color from dark to whitish grey indicates increased removal of an unwanted fixed carbon. Despite relatively high contents of un-burnt carbon, based on the XRD and EDX results, the WSA, subjected to burning temperature of $550{ }^{\circ} \mathrm{C}$, was selected for grinding to convert it into a fine powder. The detailed discussion about the selection, amorphousness (XRD analysis), and chemical composition (EDX analysis) of WSA is presented later in the results and discussion section. For grinding, a laboratory scaled ball mill, as shown in Figure 1b, was used and the WSA was milled for a duration of $2 \mathrm{~h}$ to achieve the desired fineness and specific surface area (SSA), which is a known preliminary requirement for the materials to be pozzolanic.

The particle size analysis of grounded WSA was carried out by using the MicroBrook 2000LD laser particle size analyzer. Figure 3 shows the particle size distribution of cement and WSA used in this study. Based on the comparison, it can be seen that WSA contains a higher percentage of smaller particles (finer than 20-micron) as compared to cement. While, on the other hand, the percentage of relatively coarser particles (larger than 20-microns) were high in WSA. The values of SSA of cement and WSA, as calculated using MicroBrook, were estimated as 0.259 and $0.282 \mathrm{~m}^{2} / \mathrm{g}$, respectively. Based on a comparison, it is clear that the SSA of WSA is slightly higher than cement. This might be attributed to the presence of higher percentage of finer particles in WSA as compared to cement. Moreover, the $d_{10}, d_{50}$, and $d_{90}$ sizes were also calculated for both cement and WSA and listed in Table 2. 

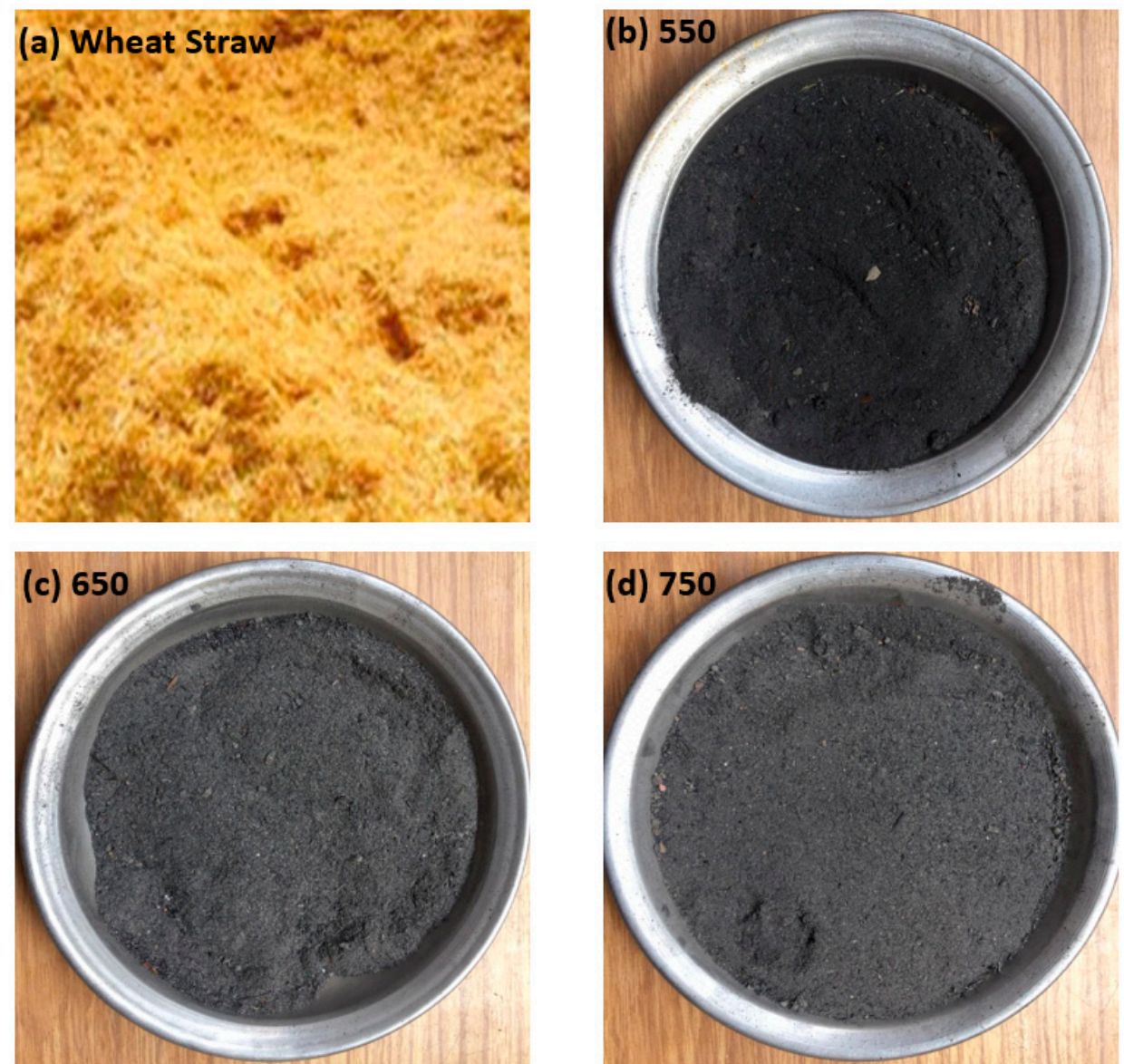

Figure 2. (a) Raw wheat straw before burning. (b) WSA from burning at $550{ }^{\circ} \mathrm{C}$. (c) WSA from burning at $650{ }^{\circ} \mathrm{C}$ and (d) WSA from burning at $750{ }^{\circ} \mathrm{C}$.

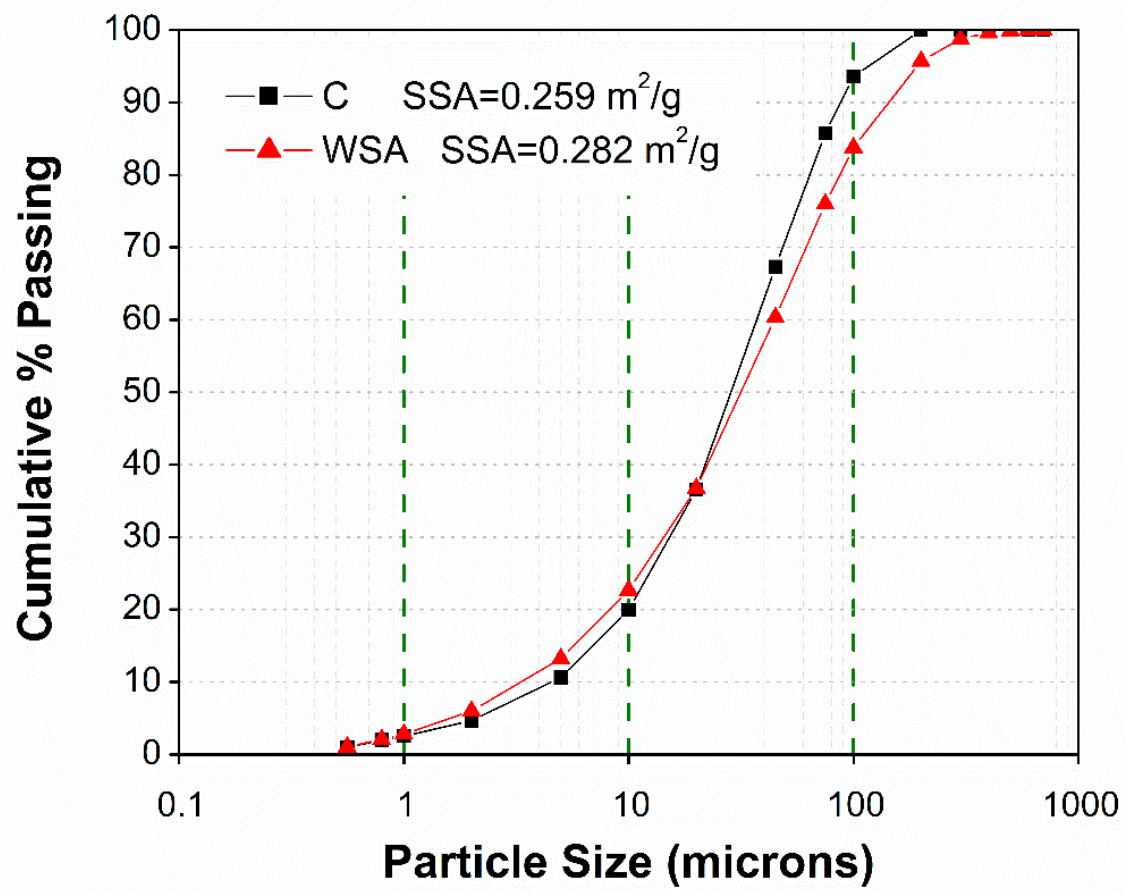

Figure 3. Particle size distribution of cement and WSA. 
Table 2. Summary of $\mathrm{d}_{10}, \mathrm{~d}_{50}$, and $\mathrm{d}_{90}$ sizes of Cement and WSA.

\begin{tabular}{cccc}
\hline Materials & $\mathbf{d}_{\mathbf{1 0}}(\mu \mathrm{m})$ & $\mathbf{d}_{\mathbf{5 0}}(\mu \mathrm{m})$ & $\mathbf{d}_{\mathbf{9 0}}(\mu \mathrm{m})$ \\
\hline Cement & 4.682 & 29.15 & 86.56 \\
Wheat Straw Ash & 3.562 & 32.21 & 134.3 \\
\hline
\end{tabular}

\subsubsection{Coarse and Fine Aggregates}

The coarse aggregate is a particulate material, which retains on sieve No. 4. The size selection of coarse aggregates mainly depends upon the nature as well as the type of concrete work. The coarse aggregate (crushed, angular, and non-porous), used in this study, was obtained from the Jamrud quarry with a nominal maximum size of $19 \mathrm{~mm}$. Before using in the concrete mix, aggregates were thoroughly washed with clean water in order to remove any deleterious materials and dust particles stuck on the surface of aggregates. Standard methods, specified in ASTM C33 and C127, were employed to calculate the fineness modulus of coarse aggregates and to measure its physical properties such as specific gravity and absorption capacity. The fineness modulus, specific gravity, and absorption capacity of coarse aggregates were $7.2 \%, 2.65 \%$, and $0.82 \%$, respectively.

The river sand was obtained from Lawrancepur and Sieving was performed on the sand sample using sieve No. 4 in order to remove particles of a size greater than $4.75 \mathrm{~mm}$. Subsequently, the sieve analysis of the oven-dried sample was performed according to ASTM C136. Table 3 shows the test results of sieve analysis and the fineness modulus of sand passing sieve No. 4 . The specific gravity and absorption of sand were calculated according to ASTM C128. The values of fineness modulus, specific gravity, and absorption capacity of fine aggregate were $2.69 \%, 2.63 \%$, and $1.03 \%$, respectively.

Table 3. Grain size distribution and fineness modulus of sand [ASTM C128].

\begin{tabular}{|c|c|c|c|c|c|}
\hline Sieve \# & Sieve Size (mm) & Weight Retained (g) & Weight Retained (\%) & Cumulative Passing (\%) & Cumulative Retained (\%) \\
\hline $3 / 8$ inch & 9.5 & 0 & 0 & 100 & 0 \\
\hline No. 4 & 4.75 & 0 & 0 & 100 & 0 \\
\hline No. 8 & 2.36 & 23 & 4.6 & 95.4 & 4.60 \\
\hline No. 16 & 1.18 & 74 & 14.8 & 80.6 & 19.4 \\
\hline No. 30 & 0.600 & 187 & 37.4 & 43.2 & 56.8 \\
\hline No. 50 & 0.300 & 151 & 30.2 & 13.0 & 87.0 \\
\hline No. 100 & 0.150 & 55.1 & 11.0 & 2.0 & 98.0 \\
\hline \multicolumn{2}{|r|}{ Pan } & 9.7 & 1.94 & - & - \\
\hline
\end{tabular}

\subsubsection{Water}

The water used in experimental works was ground water free of any suspended/colloidal particles and other impurities. The same quality of water was also used for the moist curing of mortar cubes and concrete cylinders.

\subsection{Mortar and Concrete Mixture Proportions}

The mixture proportion of mortar cubes was selected according to ASTM C109. The cement to sand and water to cementitious material $(\mathrm{w} / \mathrm{cm})$ ratios of mortar were kept as 1 to 2.75 and 0.485 , respectively. Table 4 shows the details of the mixture proportion of control as well as mortars containing different percentages of WSA $(15 \%, 20 \%, 25 \%$, and $30 \%)$ as a partial substitute of cement.

After mortar, mixture proportions of concrete were designed according to ACI 211.1-91 for normal strength concrete. The details of mixture proportions of control concrete without and with different percentages of WSA $(15 \%, 20 \%, 25 \%$, and $30 \%)$ as a partial replacement of cement are listed in Table 5 . 
Table 4. Mix proportions of control mortar and mortar containing WSA ( $\mathrm{w} / \mathrm{cm}=0.485)$.

\begin{tabular}{cccccc}
\hline & & \multicolumn{3}{c}{ Quantities per Batch (g) for Nine 50-mm Mortar Specimens $^{\mathbf{3}}$} \\
\hline Mix ID & Cement Replacement (\%) & W & C & WSA & Sand (s) \\
\hline Control Mortar (CM) & 0 & 364 & 750 & 0 & 2062.5 \\
15\% WSA (MWSA15) & 15 & 364 & 637.5 & 112.5 & 2062.5 \\
20\% WSA (MWSA20) & 20 & 364 & 600 & 150 & 2062.5 \\
25\% WSA (MWSA25) & 25 & 364 & 562.5 & 187.5 & 2062.5 \\
$30 \%$ WSA (MWSA30) & 30 & 364 & 525 & 225 & 2062.5 \\
\hline
\end{tabular}

Table 5. Mix proportions of control concrete and concrete containing WSA $(\mathrm{w} / \mathrm{cm}=0.63)$.

\begin{tabular}{|c|c|c|c|c|c|c|c|c|}
\hline \multirow[b]{2}{*}{ Mix ID } & \multirow[b]{2}{*}{ Cement Replacement (\%) } & \multicolumn{7}{|c|}{ Unit Weight $\left(\mathrm{kg} / \mathrm{m}^{3}\right)$} \\
\hline & & $\mathrm{w} / \mathrm{cm}$ & $\mathbf{s} / \mathbf{a}$ & $\mathbf{W}$ & $\mathrm{C}$ & WSA & FA & CA \\
\hline Control Concrete (C) & 0 & & & & 290 & 0 & & \\
\hline $15 \%$ WSA (WSA15) & 15 & & & & 246.5 & 43.5 & & \\
\hline $20 \%$ WSA (WSA20) & 20 & 0.63 & 40.7 & 180 & 232 & 58 & 753 & 1053 \\
\hline $25 \%$ WSA (WSA25) & 25 & & & & 217.5 & 72.5 & & \\
\hline $30 \%$ WSA (WSA30) & 30 & & & & 203 & 87 & & \\
\hline
\end{tabular}

\subsection{Specimen Preparation and Test Methods}

\subsubsection{Compressive Strength and Porosity of Mortars}

For each mortar mix (Table 4), 12 identical mortar cubes of size $50 \mathrm{~mm}^{3}$ were cast to investigate the development of compressive strength and porosity at ages of 7, 28, and 91 days. In total, 60 mortar cubes were cast in wooden molds for all five mixes including the control as well as those containing different percentages of WSA. Mixing and casting were performed according to the standard procedure specified by ASTM C109. All the specimens were demolded after $24 \mathrm{~h}$ of casting and continuously moist-cured under standard laboratory conditions of temperature until the age of testing. A universal testing machine (UTM) was used to perform the compressive strength tests on mortar cubes, according to ASTM C109. Three identical specimens were tested at all ages to calculate the average values.

Parallel to compressive strength testing, the porosity of mortar specimens was also measured along at ages of 7,28 , and 91 days to validate the current compressive strength results of mortar cubes. The porosity of mortar cubes was determined by weighing samples in various moisture states such as the weight of the sample in water $\left(W_{w}\right)$, saturated surface dry weight $\left(W_{s s d}\right)$, and oven dried weight $\left(W_{o d}\right)$. The weight of the sample in water was measured immediately after taking the samples out from the curing tank followed by measuring the saturated surface dry weight in air. Before weighing for $W_{s s d}$, the surfaces of the cube specimen were completely wiped off with a clean fabric to achieve the desired saturated surface dry state. Subsequently, the cube specimens were dried in a $\mathrm{CO}_{2}$ free oven at $105^{\circ} \mathrm{C}$ for $24 \mathrm{~h}$ followed by measuring its $W_{o d}$. The porosity of mortar samples was calculated as follows:

$$
\rho=\frac{\left(W_{s s d}-W_{o d}\right)}{\left(W_{s s d}-W_{w}\right)} \times 100 \%
$$

where, $\rho$ is the porosity calculated in the percentage. The same method of porosity calculation was adopted by many researchers in the past [46-49].

\subsubsection{Compressive Strength of Concrete}

For each concrete mix (Table 5), nine cylindrical specimens of diameter 150-mm and height 300-mm were cast to test the development of compressive strength at ages of 7, 28, and 91 days. Concrete mixing and casting of cylinders was performed following the standard procedure specified by ASTM C39. Like mortar specimens, concrete specimens were also demolded after $24 \mathrm{~h}$ of casting followed by moist curing under standard laboratory conditions of the temperature until the age of testing. 
According to ASTM C39, capping of cylinders was done using plaster of Paris in order to achieve the desired smooth ends. This was done to ensure that the applied load was evenly distributed and uniformly placed all over the bearing surface of the cylindrical specimen. All the compression tests on concrete cylinders were performed using a UTM of capacity 200 tons. Corresponding to each age of testing $(7,28$, and 91 days), three identical specimens were tested to take their average values. A dial gauge attached to the data logger was used to record any deformation during compression tests to investigate the stress-strain relation of concrete containing different percentages of WSA and comparing it with those without WSA.

\subsubsection{Thermogravimetric Analysis of Cement Pastes}

In addition to the measurement of porosity of mortars and compression tests, TGA was also performed on a control paste sample and pastes containing $15 \%, 20 \%, 25 \%$, and $30 \%$ WSA as a substitute of cement. The purpose of this analysis was to evaluate the influence of different percentages of WSA $(15 \%, 20 \%, 25 \%$, and $30 \%)$ on pozzolanic reactivity with aging and validation of mortar and concrete strength results. The samples of pastes after curing for 28 and 91 days were grounded to powder and placed in a ceramic container of thermal gravimetric analyzer. Samples were not exposed to any prior drying and, instead, directly heated in a thermal gravimetric analyzer at a temperature range of 50 to $600{ }^{\circ} \mathrm{C}$. The rate of heat increment was set at $10^{\circ} \mathrm{C} /$ minutes using nitrogen as a medium under static condition. As a reference, alumina powder was used due to its ability to maintain the stability at higher temperatures. The software to draw a comparison graph of weight loss in different paste samples recoded the percentage of the sample weight loss in different temperature regimes.

\section{Experimental Results and Discussions}

\subsection{Characteristics of WSA}

XRD and EDX analyses were performed on WSA samples to investigate the influence of different burning temperatures $\left(550^{\circ} \mathrm{C}, 650^{\circ} \mathrm{C}\right.$, and $\left.750^{\circ} \mathrm{C}\right)$ on amorphous silica and their chemical composition, respectively. The chemical composition obtained from EDX analysis of different samples of WSA with respect to (w.r.t.) their burning temperatures is listed in Table 6. From this table, it can be seen that the amount of silica content in WSA rose with an increasing burning temperature from 550 to $750{ }^{\circ} \mathrm{C}$. Moreover, the percentage sum of major oxides $\left(\mathrm{SiO}_{2}+\mathrm{Al}_{2} \mathrm{O}_{3}+\mathrm{Fe}_{2} \mathrm{O}_{3}\right)$ also increased with increasing temperature as $49.19 \%, 53.52 \%$, and $59.45 \%$ at $550{ }^{\circ} \mathrm{C}, 650{ }^{\circ} \mathrm{C}$, and $750{ }^{\circ} \mathrm{C}$, respectively.

Despite increased percentages of silica content and major oxides, the comparison of XRD analysis showed reduced amorphousness of the silica with an increasing burning temperature (Figure 4). Memon et al. [33] also confirmed the transformation of amorphous silica into crystalline nature at a burning temperature beyond $600{ }^{\circ} \mathrm{C}$. The XRD graph of WSA burnt at $550{ }^{\circ} \mathrm{C}$ showed a visibly wide and broad peak indicating glassy (amorphous) nature of its silica. On the other hand, ashes burnt at $650{ }^{\circ} \mathrm{C}$ and $750{ }^{\circ} \mathrm{C}$ showed sharp bragg peaks reflecting their crystalline nature. Given due consideration to the high amorphous nature of WSA burnt at $550{ }^{\circ} \mathrm{C}$, it was grounded in a ball mill for $2 \mathrm{~h}$ to achieve the desired fineness required for pozzolanic materials. Subsequently, this finely grounded WSA was used as a partial substitute of cement (15\%,20\%,25\%, and 30\%) in mortar and concrete for further evaluation of its pozzolanic potential and influence on strength, stress-strain relation, and stiffness behavior. 
Table 6. Chemical composition of WSA w.r.t. burning temperatures.

\begin{tabular}{cccc}
\hline & \multicolumn{3}{c}{ Oxides (\% by Weight) } \\
\cline { 2 - 4 } Item & \multicolumn{3}{c}{ Burning Temperature $\left({ }^{\circ} \mathbf{C}\right)$} \\
\cline { 2 - 4 } & $\mathbf{5 5 0}$ & $\mathbf{6 5 0}$ & $\mathbf{7 5 0}$ \\
\hline $\mathrm{SiO}_{2}$ & 44.54 & 48.49 & 53.69 \\
$\mathrm{Al}_{2} \mathrm{O}_{3}$ & 1.87 & 1.95 & 2.04 \\
$\mathrm{Fe}_{2} \mathrm{O}_{3}$ & 2.78 & 3.08 & 3.72 \\
$\mathrm{AlO}_{2} \mathrm{O}_{3}+\mathrm{Fe}_{2} \mathrm{O}_{3}$ & 49.19 & 53.52 & 59.45 \\
$\mathrm{CaO}$ & 2.93 & 4.65 & 4.56 \\
$\mathrm{~K}_{2} \mathrm{O}$ & 29.92 & 25.92 & 21.03 \\
$\mathrm{MgO}$ & 2.34 & 1.98 & 0.98 \\
$\mathrm{Na}_{2} \mathrm{O}$ & 1.54 & 0.56 & 0.59 \\
$\mathrm{P}_{2} \mathrm{O}_{5}$ & 3.66 & 1.24 & 1.24 \\
$\mathrm{SO}_{3}$ & 6.17 & 6.24 & 4.67 \\
\hline
\end{tabular}
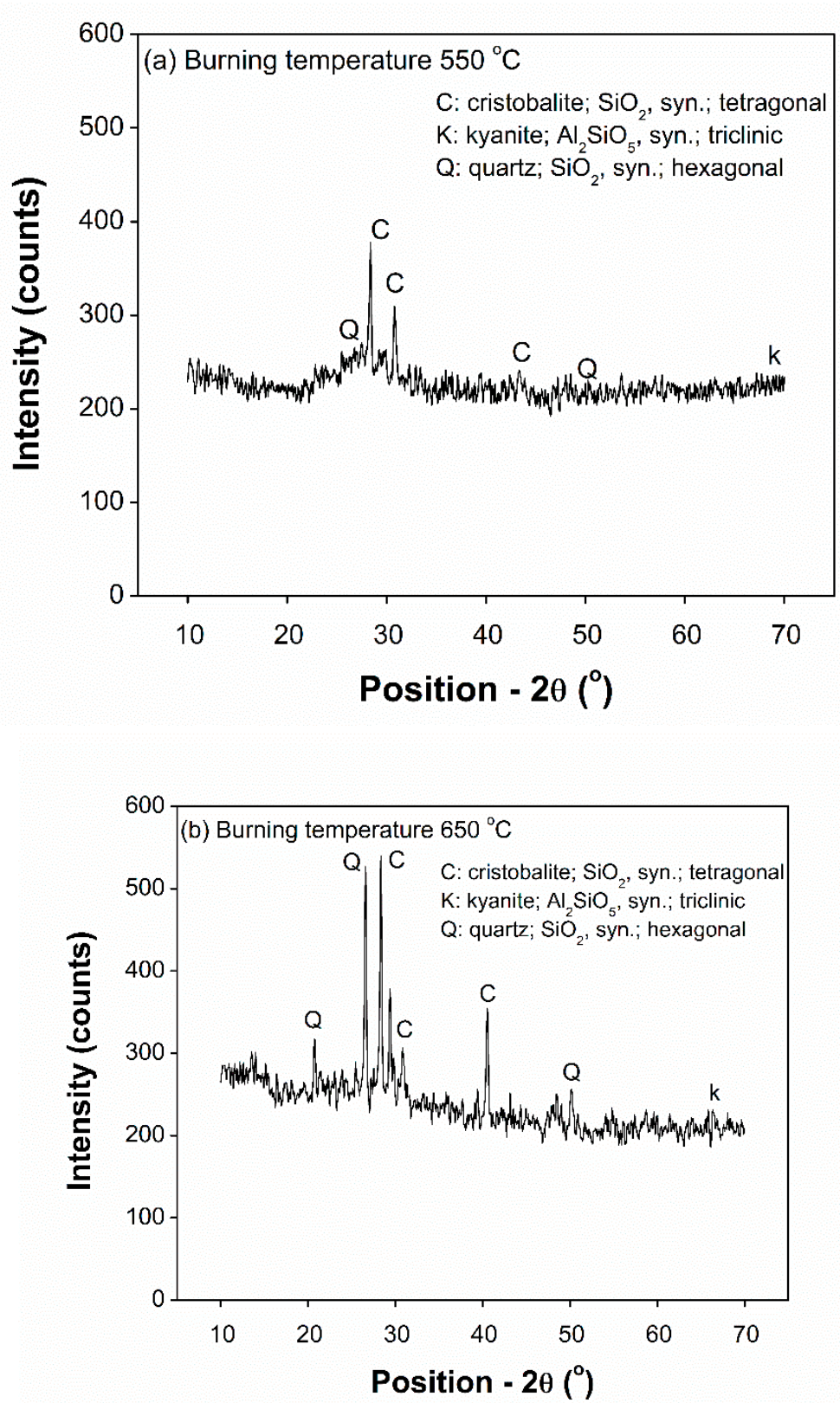

Figure 4. Cont. 


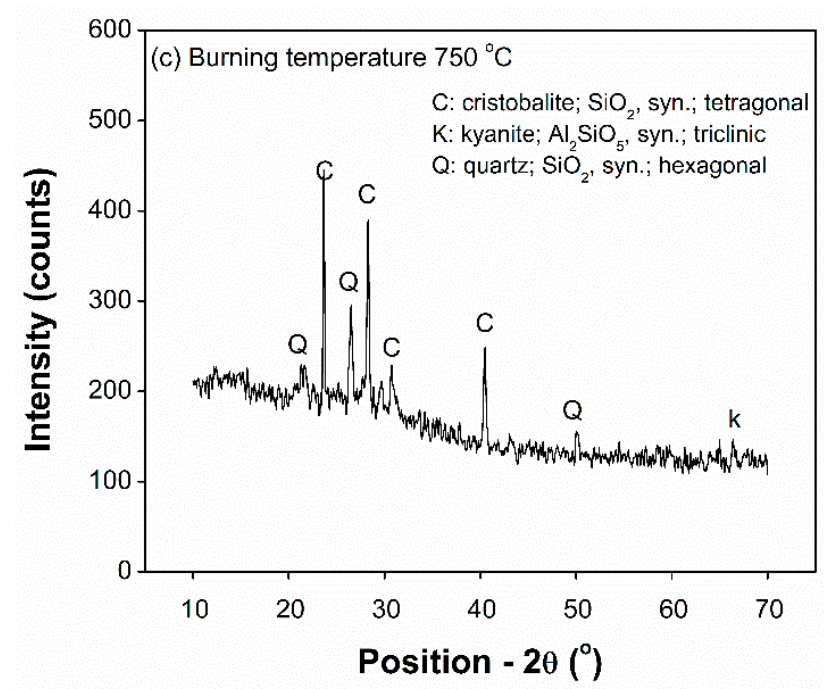

Figure 4. XRD analyses of WSA w.r.t. burning temperature: (a) $550{ }^{\circ} \mathrm{C}$, (b) $650{ }^{\circ} \mathrm{C}$, and (c) $750{ }^{\circ} \mathrm{C}$.

\subsection{Compressive Strength, Strength Activity Index, and Porosity of Mortars}

The test results of compressive strength and porosity mortar cubes along with their SAI values are listed in Table 7 . Values reported in this table were calculated by taking the average of three identical specimens.

Table 7. Compressive strength, porosity, and SAI values of mortars w.r.t. aging.

\begin{tabular}{|c|c|c|c|c|c|c|c|c|c|}
\hline \multirow{3}{*}{ Mix ID } & \multicolumn{3}{|c|}{ Compressive Strength (MPa) } & \multicolumn{3}{|c|}{ Porosity (\%) } & \multicolumn{3}{|c|}{ SAI (\%) } \\
\hline & \multicolumn{9}{|c|}{ Age (days) } \\
\hline & 7 & 28 & 91 & 7 & 28 & 91 & 7 & 28 & 91 \\
\hline $\mathrm{CM}$ & $\begin{array}{c}20.7 \\
(0.99) \text { * }\end{array}$ & $\begin{array}{c}22.3 \\
(1.81)\end{array}$ & $\begin{array}{c}27.0 \\
(1.63)\end{array}$ & 23 & 22 & 19.7 & - & - & - \\
\hline M-WSA15 & $\begin{array}{c}20.6 \\
(1.52)\end{array}$ & $\begin{array}{c}23.2 \\
(0.85)\end{array}$ & $\begin{array}{c}27.4 \\
(0.86)\end{array}$ & 25 & 20.7 & 17.3 & 99.5 & 104 & 101.5 \\
\hline M-WSA20 & $\begin{array}{c}20.6 \\
(1.16)\end{array}$ & $\begin{array}{c}21.6 \\
(1.28)\end{array}$ & $\begin{array}{c}25.8 \\
(0.89)\end{array}$ & 26 & 22.8 & 20.4 & 99.5 & 96.9 & 95.6 \\
\hline M-WSA25 & $\begin{array}{c}20.0 \\
(1.25)\end{array}$ & $\begin{array}{c}21.3 \\
(1.05)\end{array}$ & $\begin{array}{c}21.7 \\
(1.07)\end{array}$ & 31 & 23.9 & 22.7 & 96.6 & 95.5 & 80.4 \\
\hline M-WSA30 & $\begin{array}{c}19.4 \\
(1.03)\end{array}$ & $\begin{array}{c}20.9 \\
(0.92)\end{array}$ & $\begin{array}{c}21.4 \\
(0.86)\end{array}$ & 32 & 24.7 & 24 & 93.7 & 93.7 & 79.3 \\
\hline
\end{tabular}

* Values in parenthesis indicate the standard deviation of all test results of mortar.

Lastly, these average results of porosity and compressive strength were plotted against aging to compare between different mortars containing WSA and control mortar. Figures 5 and 6 show the comparison of compressive strength results and porosity, respectively. From Figure 5, it can be seen that the early-age compressive strength of mortars containing 15\% and 20\% WSA got reasonably close to that of control mortar and increased continuously with aging for mortar with 15\% WSA. At ages of 28 and 91 days, the strength enhancement in 15\% WSA mortars was noticed as 3\% and $4 \%$ higher than that of the control mortar, respectively. This was also confirmed by the porosity tests (Figure 6) corresponding to the age of 28 and 91 days where it can be clearly seen that the respective porosity values of $15 \%$ WSA mortar were lower than the control mortar. In general, the current results indicated that the porosity of mortar decreased with aging for all mortar mixes, which is clear due to the consumption of water by the hydration reaction and the generation of a solid gel in the matrix. Unlike 15\% WSA mortar, gaining good early-age strength developments in mortar with 20\% WSA was 
discontinued at later ages of 28 and 91 days and the final strength values were lower than the control mortar (Figure 5). This trend of lower strength in $20 \%$ WSA mortar was also validated through the porosity results where it was slightly higher than the control sample, which might be due to a reduced hydration/pozzolanic reaction in the presence of lower amounts of cement as compared to mortar of $15 \%$ WSA.

Moreover, the mortars with relatively higher percentages of WSA (25\% and 30\%) exhibited similar behavior to that of $20 \%$ WSA and that of the strength decreased with increasing percentage of WSA equal to or more than $20 \%$ WSA. These results were also validated through porosity tests where it drastically increased as compared to the control mortar or mortar containing $15 \%$ to $20 \%$ WSA. Lastly, the current results suggest $15 \%$ replacement of cement with WSA since it produced comparable or better strength as compared to control mortar.

Since the compressive strength of mortar reduced with an increasing percentage of WSA beyond $20 \%$, SAI was also calculated for each mortar to investigate the reactivity of WSA with cement. The SAI values listed in Table 7 were calculated, according to ASTM C311 [50]. According to ASTM C618, the SAI value for each mortar mix should be at least $75 \%$, which means that the mortar containing SCMs must have compressive strength equal to $75 \%$ of $\mathrm{CM}$ at 7 and 28 days. Although, compressive strength of mortars containing WSA as $20 \%$ or more was less than the control mortar at all ages. However, their SAI were found significantly higher than $75 \%$ regardless of a percentage of cement replacements and aging. It must be worth noting that the SAI values reduced with an increasing percentage of WSA and aging for all mortars except the one containing 15\% WSA. Tests were also performed on compressive strength of concrete to further validate the finding of this study and are discussed in the following section.

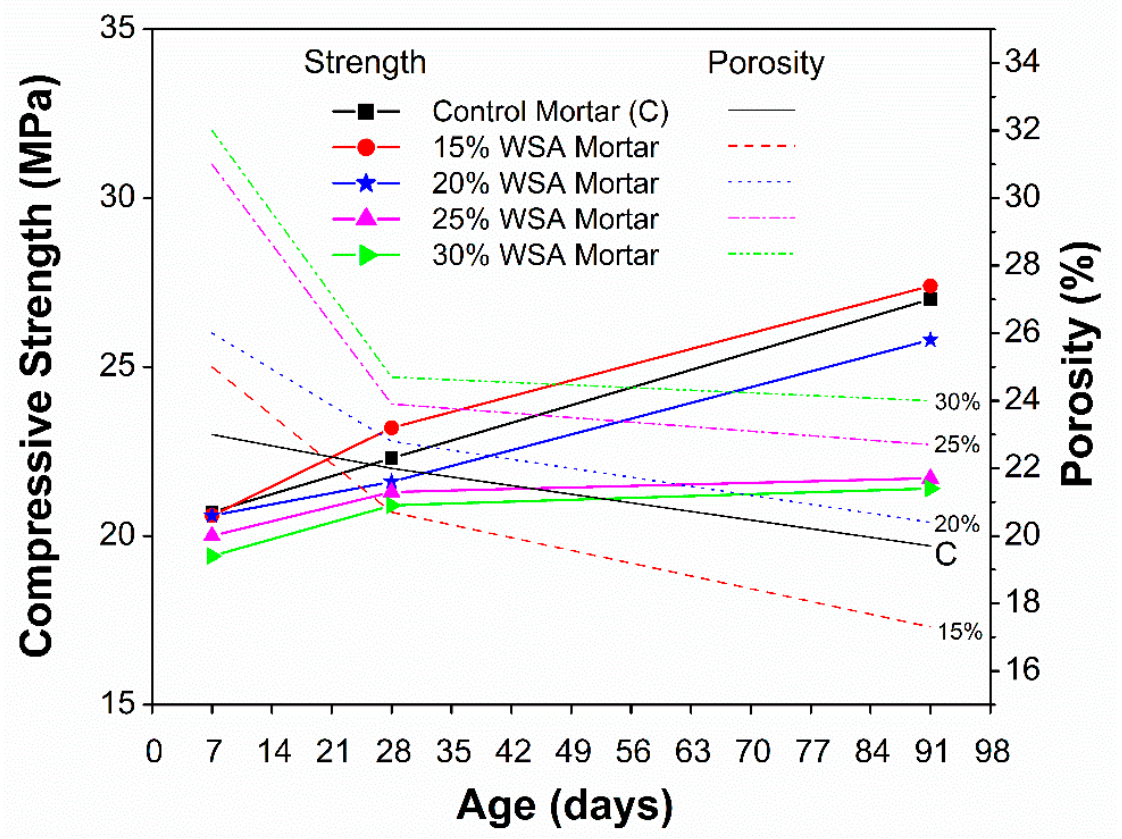

Figure 5. Comparison of strength development between control mortar and mortars containing WSA. 


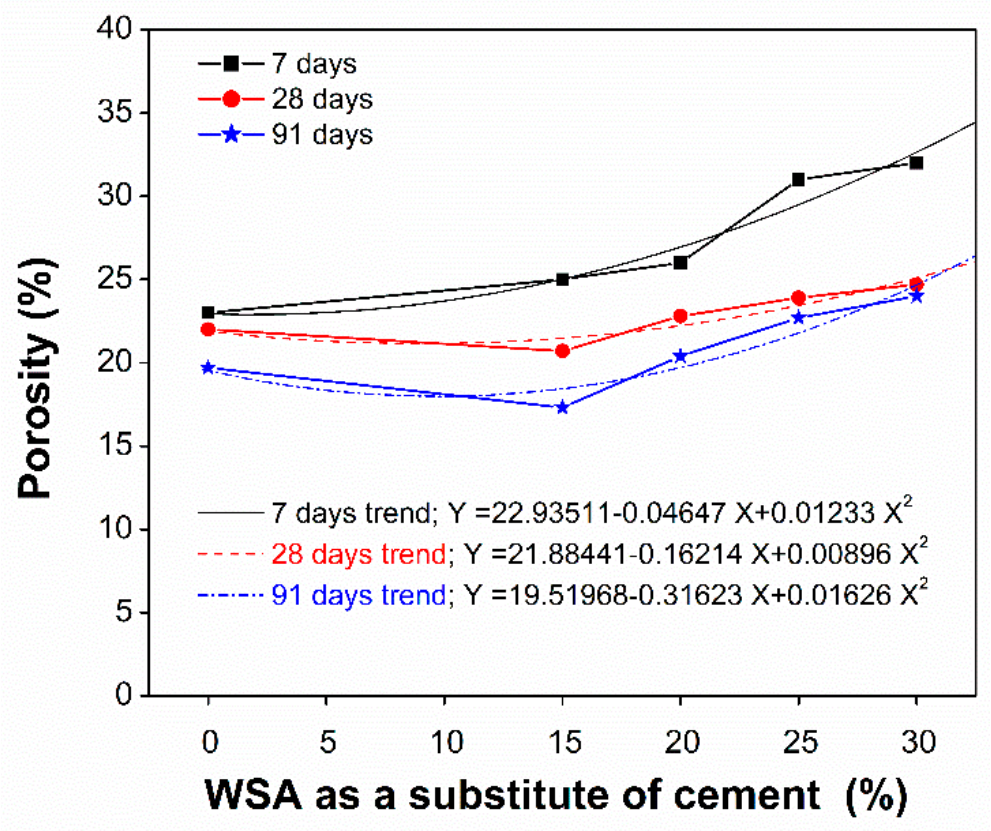

Figure 6. Influence of WSA on the porosity of mortar w.r.t. aging.

\subsection{Compressive Strength of Concrete}

The compressive strength of concrete was measured in accordance with ASTM C39 and the average values of three identical specimens are listed in Table 8. Figure 7 shows the comparison of compressive strength results between control concrete and those containing different percentages of WSA w.r.t. aging.

Table 8. Compressive strength of concrete w.r.t. aging.

\begin{tabular}{cccc}
\hline & \multicolumn{3}{c}{ Compressive Strength (MPa) } \\
\cline { 2 - 4 } Mix ID & \multicolumn{3}{c}{ Age (days) } \\
\cline { 2 - 4 } & $\mathbf{7}$ & $\mathbf{2 8}$ & $\mathbf{9 1}$ \\
\hline C & 13.3 & 19.5 & 20.3 \\
WSA15 & 12.8 & 19.0 & 21.7 \\
WSA20 & 12.7 & 18.6 & 21.3 \\
WSA25 & 10.1 & 15.3 & 14.6 \\
WSA30 & 7.2 & 10.7 & 12.8 \\
\hline
\end{tabular}

Just like mortars, the compressive strength of concrete containing 15\% and 20\% WSA was slightly less than the control concrete at ages of 7 and 28 days. At an age of 91 days, it increased by $6 \%$ and $4 \%$ when compared to the control sample in concrete containing $15 \%$ and $20 \%$ WSA, respectively. The compressive strength in concrete containing higher percentages of WSA such as $25 \%$ and $30 \%$ was reduced drastically as compared to control concrete at all ages. However, as discussed in the preceding section, the SAI values of mortars of more than $75 \%$ still suggested that the higher percentages of WSA such as $25 \%$ or $30 \%$ can be used to produce sustainable concrete. For instance, this includes projects where high early or ultimate strength of concrete are not required. 


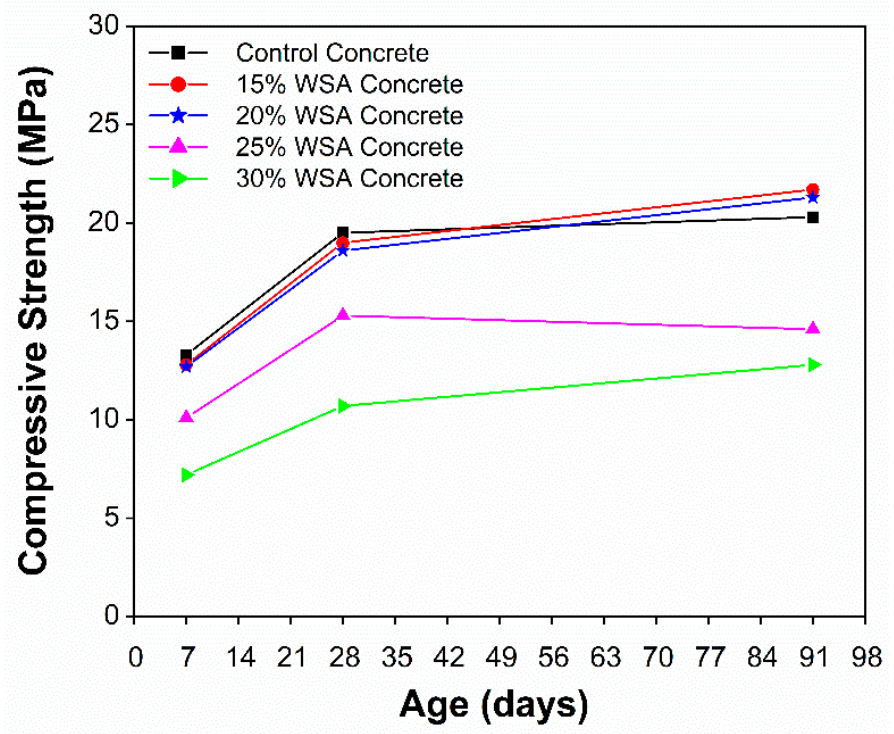

Figure 7. Comparison of strength development between control concrete and concretes containing WSA.

In addition to the simple comparison of compressive strengths, this study has further investigated the influence of WSA on general stress-strain behavior of concrete. Figure 8 shows the comparison of the stress-stain relation with aging between control concrete and concrete containing different percentages of WSA. It can be seen that the general trend of stiffness and toughness of concrete reduced with an increasing percentage of WSA. However, at relatively low percentage replacements, the stiffness was significantly enhanced at all ages such as for concrete containing $15 \%$ and $20 \%$ WSA. Along with stiffness, their toughness seemed comparable to control concrete. Particularly, the ductility and toughness of concrete containing 15\% WSA was significantly higher than the control concrete at age of 91 days followed by the concrete containing $20 \%$ WSA.

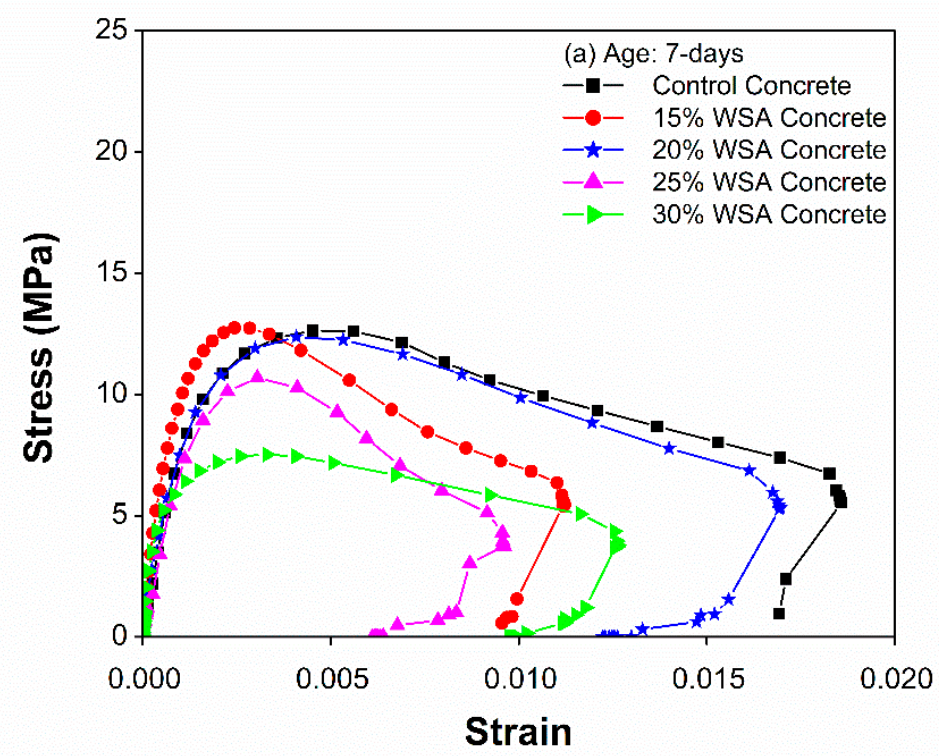

Figure 8. Cont. 

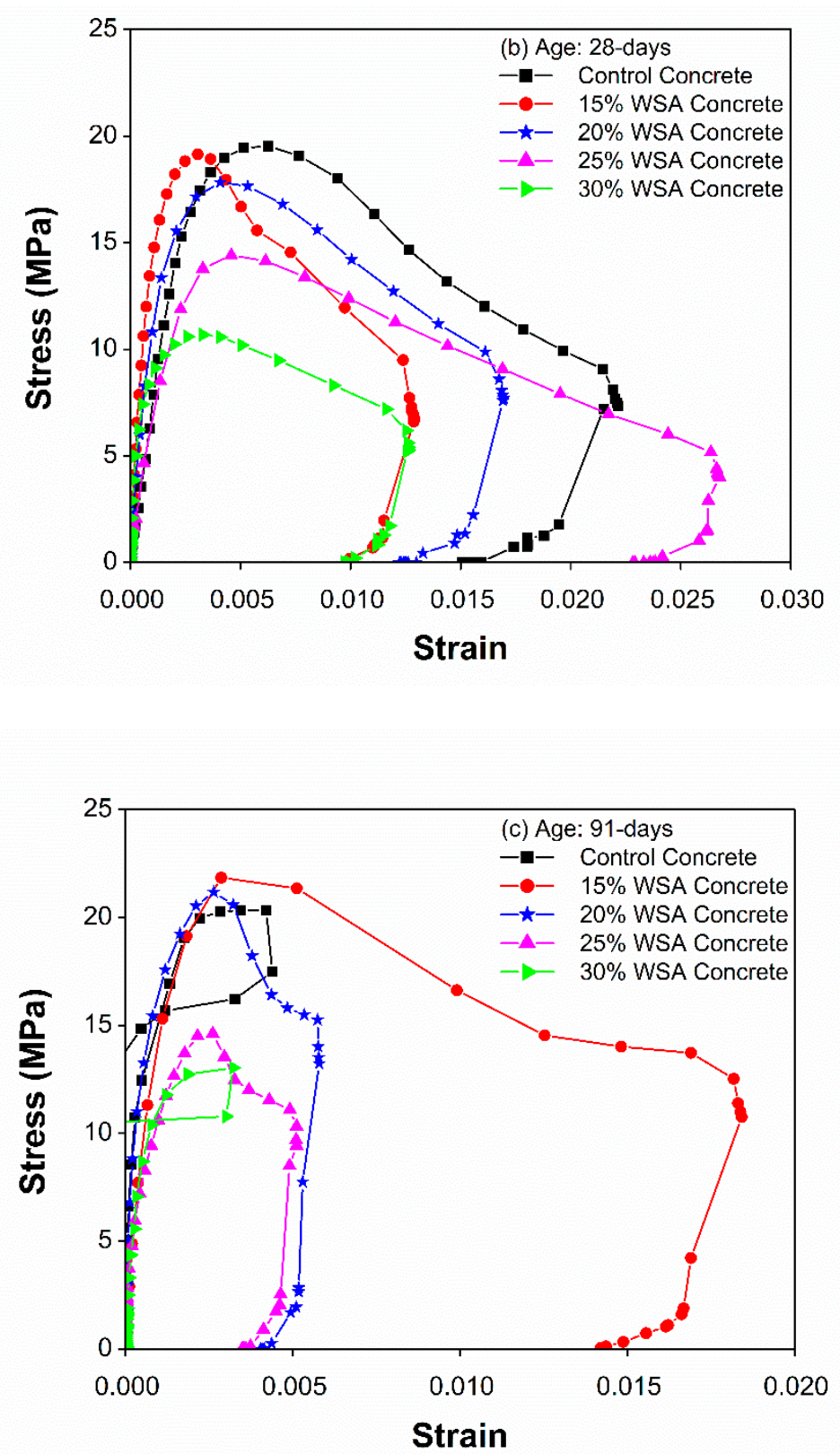

Figure 8. Comparison of stress-strain relation between control concrete and concrete containing different percentage of WSA at an age of: (a) 7-days, (b) 28-days, and (c) 91-days.

\subsection{Thermogravimetric Analysis}

Figure 9 shows the comparison of TGA with aging (28 and 91 days) between different pastes with and without WSA. As expected, four characteristic endothermic stages were recognized for all paste samples [51]. The first stage between temperatures of 25 to $100{ }^{\circ} \mathrm{C}$ was attributed to evaporation of surface absorbed water gained by the sample during the cooling stage. The second endothermic effect between 100 and $350^{\circ} \mathrm{C}$ was mainly due to the dehydration of C-S-H, ettringites, and calcium aluminate hydrates [52]. The third effect between temperature ranges from 430 to $460{ }^{\circ} \mathrm{C}$ showed decomposition of $\mathrm{Ca}(\mathrm{OH})_{2}$ formed during the hydration of cement [53]. The final endothermic effect at about $790{ }^{\circ} \mathrm{C}$ could be attributed mainly to de-carbonation of calcium carbonate in the hydrated compounds.

The utilization of $\mathrm{Ca}(\mathrm{OH})_{2}$ is being used as an indirect assessment of pozzolanic reactivity in the cement pozzolan pastes [54-56]. It is well known that the amorphous silica present in the pozzolana reacts with portlandite $\left(\mathrm{Ca}(\mathrm{OH})_{2}\right)$ as produced during a normal hydration reaction and form C-S-H. The comparison of TGA analysis curves showed maximum weight loss occurred in 
control samples between 430 and $460^{\circ} \mathrm{C}$ irrespective of the curing age ( 28 or 91 days). The initial steep slopes observed can be attributed to a loss of chemically bound water related to AFm, AFt, or C-S-H phase as well as free moisture present in the samples. As compared to the control samples, weight loss within this temperature range reduced in pastes containing WSA irrespective of the percentage substitution. The least weight loss was observed in paste containing 15\% WSA, which indicates its greatest pozzolanic reactivity as compared to other samples. Moreover, this weight loss increased with an increasing percentage of WSA from $15 \%$ to $30 \%$. Though insignificant, relatively lesser weight loss in pastes containing WSA as $20 \%, 25 \%$, and $30 \%$ suggested minor pozzolanic reactivity at 28 days.

As previously mentioned, the weight loss in the control sample between 430 and $460{ }^{\circ} \mathrm{C}$ increased with aging from 28 to 91 days, which indicates its continued hydration, and, thus, generates more $\mathrm{Ca}(\mathrm{OH})_{2}$. Consequently, the further reduced amount of portlandites in paste containing $15 \%$ WSA clearly showed improvement in pozzolanic reactivity at later ages as well. The slight decrease of $\mathrm{Ca}(\mathrm{OH})_{2}$ in $20 \%$ WSA paste at 91 days revealed its comparatively better pozzolanic reactivity at later ages. An insignificant reduction of $\mathrm{Ca}(\mathrm{OH})_{2}$, particularly at later ages, in pastes with a relatively higher amount of WSA, suggested limiting the amount of WSA to $20 \%$, in order to avoid its adverse effects on strength and durability properties of cementitious composites.
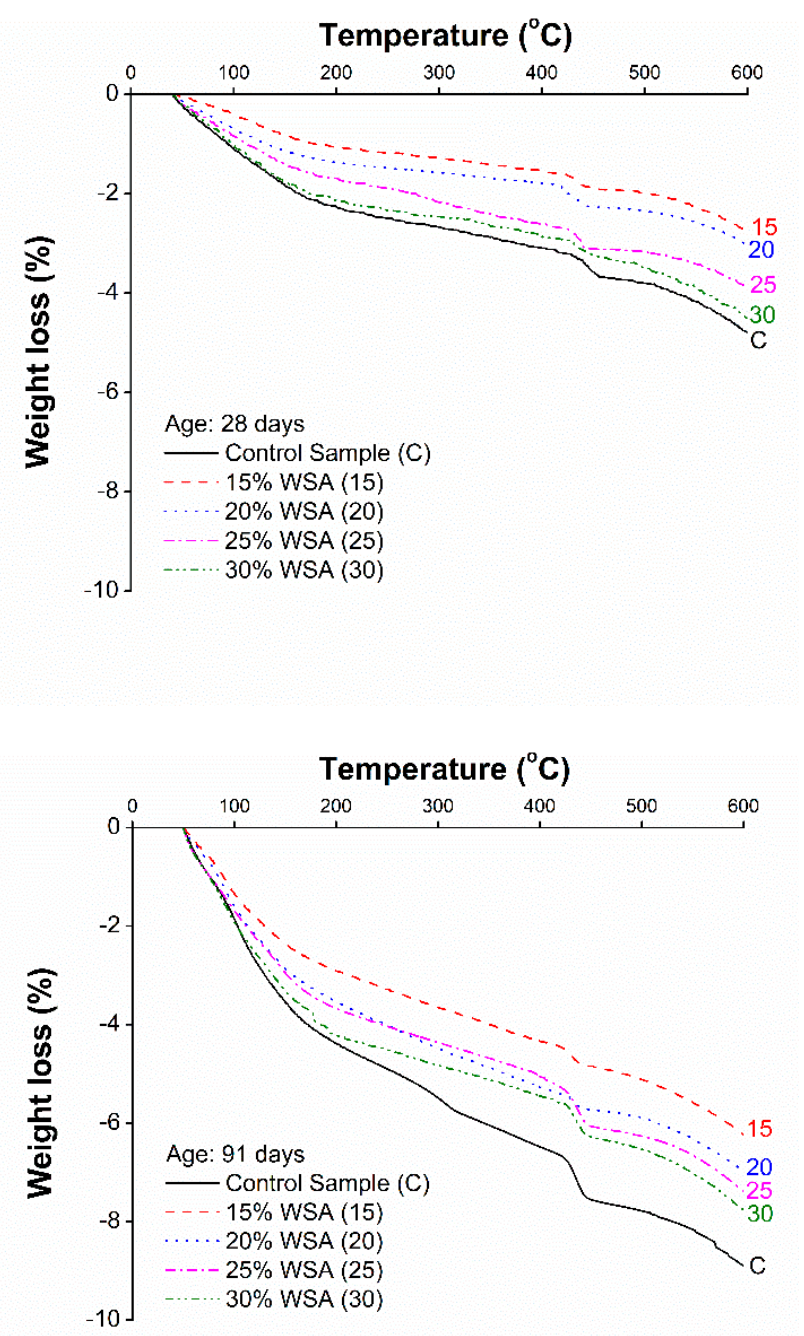

Figure 9. Comparison of TGA w.r.t. aging between different pastes with and without WSA. 


\section{Conclusions}

A locally available WSA in Khyber Pakhtunkhwa province of Pakistan was studied in this research to investigate its potential as sustainable construction material by evaluating its pozzolanic activity and mechanical performance. At first, various samples of raw wheat straw were burnt to ashes at different temperatures $\left(550{ }^{\circ} \mathrm{C}, 650{ }^{\circ} \mathrm{C}\right.$, and $\left.750{ }^{\circ} \mathrm{C}\right)$ to find out the optimum burning temperature and the duration to produce the highest amount of silica and amorphous nature of its constituent materials. Based on the findings of XRD and EDX analyses, amorphous WSA attained from burning at $550{ }^{\circ} \mathrm{C}$ was ground to a required fineness in a ball mill for $2 \mathrm{~h}$. Lastly, the finest WSA was used in mortar and concrete from $15 \%$ to $30 \%$ as a partial substitute of cement to investigate its influence on mechanical strength and the stress-strain relation. At the end, the porosity of mortar cubes and TGA were performed to validate the current strength results and the pozzolanic reaction of WSA. Based on the current findings, the following conclusions were drawn from this study:

- $\mathrm{XRD}$ and EDX analyses indicated that the amounts of essential pozzolanic elements $\left(\mathrm{SiO}_{2}, \mathrm{Al}_{2} \mathrm{O}_{3}\right.$, $\mathrm{Fe}_{2} \mathrm{O}_{3}$ ) in WSA increased with an increasing burning temperature. However, WSA was transformed from an amorphous to a crystalline nature with an increasing temperature from 550 to $750{ }^{\circ} \mathrm{C}$.

- WSA burnt at $550{ }^{\circ} \mathrm{C}$ for $5 \mathrm{~h}$ was found to be highly amorphous in nature with fewer pozzolanic elements by $8 \%$ and $20 \%$ than the WSA obtained from burning at 650 and $750{ }^{\circ} \mathrm{C}$, respectively.

- The strength of mortar decreased with an increasing percentage of WSA while the porosity of mortar increased with an increasing percentage of WSA. However, the mortar containing 15\% WSA has produced almost identical strength to that of control mortar at 7 days, and even better at later ages where it was 3\% and 4\% higher than the control mortar at ages of 28 and 91 days, respectively. The compressive strength results of mortar containing 15\% WSA were also validated through porosity tests, which showed reduced values at later ages as compared to the porosity of control mortar. Although, the strength of mortars containing 20\%, 25\%, and 30\% WSA was lower than the control mortar at all ages. However, their SAI values were more than 75\%, which, in other words, meets the ASTM C618 requirements for pozzolanic materials.

- A similar trend of compressive strength development to that of mortar were observed in concrete containing WSA except at 91 days in concrete containing 20\% WSA. Contrary to mortar results, the compressive strength of concrete containing 20\% WSA was higher than the control mortar at 91 days. Moreover, the stress-strain relation of concrete indicated that the stiffness and toughness of concrete reduced with an increasing percentage of WSA. The stress-strain relation indicated that the stiffness of concrete containing 15\% and 20\% WSA has significantly improved at all ages. Moreover, their toughness were also comparable to control concrete. Specifically, the toughness of concrete containing 15\% WSA was significantly higher than the control concrete at an age of 91 days followed by the concrete containing 20\% WSA.

- The highest pozzolanic reactivity of 15\% WSA at both 28 and 91 days was validated through TGA results since it indicated the least mass loss between 430 and $460{ }^{\circ} \mathrm{C}$ among all paste samples containing WSA as well as the control. On the other hand, the highest mass loss, as expected, was observed in control samples followed by the pastes containing a relatively high percentage of WSA $(30 \%, 25 \%$, and 20\%). However, lower mass losses in pastes containing 20\%, 25\%, and $30 \%$ WSA as compared to control samples supported their minor pozzolanic reactivity. Moreover, the slightly decreased $\mathrm{Ca}(\mathrm{OH})_{2}$ content at 91 days in the sample containing $20 \%$ WSA revealed its better pozzolanic reactivity at later ages. Based on this, authors recommend using WSA up to $20 \%$ as a substitute of cement clinker to produce sustainable cementitious composites.

Author Contributions: M.N.A., T.M., K.S., and K.K. contributed to the design of this research. T.M. and M.A. contributed to performing the experiments started from collecting wheat straw (WS) and other concrete ingredients, burning WS, mixing, casting, demolding, and curing of mortar and concrete specimens. T.M. and K.S. performed the XRD, EDX analysis, and mechanical testing. M.N.A., T.M., and K.K. has contributed in writing the 'Introduction' and the 'Materials and Method' section of manuscript and critically analyzed and discussed the results. M.N.A., T.M., K.S., and K.K. has contributed to preparing and writing the manuscript. 
Funding: This research was funded by the Deanship of Scientific Research (DSR) at the King Faisal University (KFU) through its "Nasher Track, grant number 186031" and "The APC was funded by the DSR at KFU through the same Nasher Track grant number 186031".

Acknowledgments: The authors wish to express their gratitude for the financial support that has made this study possible.

Conflicts of Interest: The authors declare no conflict of interest. The founding sponsors had no role in the design of the study, in the collection, analyses, or interpretation of data, in the writing of the manuscript, nor in the decision to publish the results.

\section{References}

1. Klee, H. The Cement Sustainability Initiative: Recycling Concrete; World Business Council for Sustainable Development (WBCSD): Geneva, Switzerland, 2009.

2. WBCSD-IEA. Cement Technology Roadmap 2009_Carbon Emissions Reductions up to 2050; WBCSD-IEA: Geneva, Switzerland, 2009.

3. WBCSD-CSI. Cement Industry Energy and CO2 Performance "Getting the Numbers Right"; WBCSD-CSI: Washington, DC, USA, 2009.

4. Cement Industry Federation. CIF Cement Industry Environment Report; Cement Industry Federation: Forrest, Australia, 2003.

5. Humphreys, K.; Mahasenan, M. Toward a Sustainable Cement Industry: Climate Change. Substudy 8; World Business Council for Sustainable Development (WBCSD): Geneva, Switzerland, 2002.

6. Campione, G.; Cavaleri, L.; Minafò, G.; Miraglia, N. The use of pumice lightweight concrete for masonry applications. Mater. Struct. 2012, 45, 679-693.

7. Fuller, W.B.; Thompson, S.E. The laws of proportioning concrete. Trans. Am. Soc. Civ. Eng. 1907, 59, 67-143.

8. Cascardi, A.; Longo, F.; Micelli, F.; Aiello, M.A. Compressive strength of confined column with Fiber Reinforced Mortar (FRM): New design-oriented-models. Constr. Build. Mater. 2017, 156, 387-401. [CrossRef]

9. Maddaloni, G.; Cascardi, A.; Balsamo, A.; Di Ludovico, M.; Micelli, F.; Aiello, M.A.; Prota, A. Confinement of full-scale masonry columns with FRCM systems. Key Eng. Mater. 2017, 747, 374-381. [CrossRef]

10. Ombres, L.; Verre, S. Shear Performance of FRCM Strengthened RC Beams; American Concrete Institute, ACI Special Publication (SP 324): Farmington Hills, MI, USA, 2017.

11. International Federation for Structural Concrete fib (Ed.) Guidelines for Green Concrete Structures; fib: Lausanne, Switzerland, 2012.

12. Gartner, E. Industrially interesting approaches to low- $\mathrm{CO}_{2}$ cement. Cem. Concr. Res. 2004, 34, 1489-1498. [CrossRef]

13. Ogbeide, S.O. Developing an optimization model for $\mathrm{CO}_{2}$ reduction in cement production process. J. Eng. Sci. Technol. Rev. 2012, 3, 85-88. [CrossRef]

14. Yang, K.H.; Jung, Y.B.; Cho, M.S.; Tae, S.H. Effect of supplementary cementitious materials on reduction of $\mathrm{CO}_{2}$ emissions from Concrete. In Handbook of Low Carbon Concrete, 1st ed.; Butterworth-Heinemann: Oxford, UK, 2017; pp. 89-110.

15. Hemalatha, T.; Ramaswamy, A. A review on fly ash characteristics-towards promoting high volume utilization in developing sustainable concrete. J. Clean. Prod. 2017, 147, 546-559. [CrossRef]

16. Siddique, R. Utilization of silica fume in concrete: Review of hardened properties. Resour. Conserv. Recycl. 2011, 55, 923-932. [CrossRef]

17. Ozbay, E.; Erdemir, M.; Durmus, H.I. Utilization and efficiency of ground granulated blast furnace slag on concrete properties-A review. Constr. Build. Mater. 2016, 105, 423-434. [CrossRef]

18. Paris, J.M.; Roessler, J.G.; Ferraro, C.C.; DeFord, H.D.; Townsend, T.G. A review of waste products utilized as supplements to Portland cement in concrete. J. Clean. Prod. 2016, 121, 1-18. [CrossRef]

19. Dadsetan, S.; Bai, J. Mechanical and microstructural properties of self-compacting concrete blended with metakaolin, ground granulated blast-furnace slag and fly ash. Constr. Build. Mater. 2017, 146, 658-667. [CrossRef]

20. Khan, K.; Amin, M.N. Influence of fineness of volcanic ash and its blends with quarry dust and slag on compressive strength of mortar under different curing temperatures. Constr. Build. Mater. 2017, 154, 514-528. [CrossRef] 
21. Khurram, N.; Khan, K.; Saleem, M.U.; Amin, M.N.; Akmal, U. Effect of Elevated Temperatures on Mortar with Naturally Occurring Volcanic Ash and Its Blend with Electric Arc Furnace Slag. Adv. Mater. Sci. Eng. 2018, 2018, 5324036. [CrossRef]

22. Amin, M.N.; Khan, K.; Saleem, M.U.; Khurram, N.; Niazi, M.U.K. Influence of Mechanically Activated Electric Arc Furnace Slag on Compressive Strength of Mortars Incorporating Curing Moisture and Temperature Effects. Sustainability 2017, 9, 1178. [CrossRef]

23. Amin, M.N.; Khan, K.; Saleem, M.U.; Khurram, N.; Niazi, M.U.K. Aging and Curing Temperature Effects on Compressive Strength of Mortar Containing Lime Stone Quarry Dust and Industrial Granite Sludge. Materials 2017, 10, 642. [CrossRef] [PubMed]

24. Amin, M.N. Influence of Fineness of Recycled Glass Waste and Slag on Compressive Strength of Sulphate Resisting Cement Mortars. Open Constr. Build. Technol. J. 2017, 11, 314-331. [CrossRef]

25. Cordeiro, G.C.; Toledo, R.D.; Tavares, L.M.; Fairbairn, E.M.R. Pozzolanic activity and filler effect of sugar cane bagasse ash in Portland cement and lime mortars. Cem. Concr. Compos. 2008, 30, 410-418. [CrossRef]

26. Rukzon, S.; Chindaprasirt, P. Utilization of bagasse ash in high-strength concrete. Mater. Des. 2012, 34, 45-50. [CrossRef]

27. Zhang, M.H.; Malhotra, V.M. High-performance concrete incorporating rice husk ash as supplementary cementing materials. ACI Mater. J. 1996, 93, 629-636.

28. Habeeb, G.A.; Fayyadh, M.M. Rice husk ash concrete: The effect of RHA average particle size on mechanical properties and drying shrinkage. Aust. J. Basic Appl. Sci. 2009, 3, 1616-1622.

29. FAO World Food Situation. Available online: http://www.fao.org/worldfoodsituation/csdb/en/ (accessed on 20 October 2018).

30. Largest Wheat Producing Countries Worldwide in 2017/2018. Available online: https:/ /www.statista.com/ statistics/237912/global-top-wheat-producing-countries/ (accessed on 20 October 2018).

31. Pan, X.; Sano, Y. Fractionation of wheat straw by atmospheric acetic acid process. Bioresour. Technol. 2005, 96, 1256-1263. [CrossRef] [PubMed]

32. Kadam, K.L.; Forrest, L.H.; Jacobson, W.A. Rice straw as a lignocellulosic resource: Collection, processing, transportation, and environmental aspects. Biomass Bioenergy 2000, 18, 369-389. [CrossRef]

33. Shazim, A.M.; Israr, W.; Muhammad, K.K.; Muhammad, A.T.; Madina, B. Environmentally Friendly Utilization of Wheat Straw Ash in Cement-Based Composites. Sustainability 2018, 10, 1322.

34. Binici, H.; Aksogan, O. The use of ground blast furnace slag, chrome slag and corn stem ash mixture as a coating against corrosion. Constr. Build. Mater. 2011, 25, 4197-4201. [CrossRef]

35. Biricik, H.; Aköz, F.; lhan, I.B.; Tulgar, A.N. Study of pozzolanic properties of wheat straw ash. Cem. Concr. Res. 1999, 29, 637-643. [CrossRef]

36. Al-Akhras, N.M.; Abu-Alfoul, B.A. Effect of wheat straw ash on mechanical properties of autoclaved mortar. Cem. Concr. Res. 2002, 32, 859-863. [CrossRef]

37. Khushnood, R.A.; Rizwan, S.A.; Memon, S.A.; Tulliani, J.-M.; Ferro, G.A. Experimental Investigation on Use of Wheat Straw Ash and Bentonite in Self-Compacting Cementitious System. Adv. Mater. Sci. Eng. 2014, 2014, 832508. [CrossRef]

38. Visvesvaraya, H.C. Recycling of agricultural wastes with special emphasis on rice-husk ash, Use of vegetable plants and fibers as building materials. In Proceedings of the Joint Symposium RILEM/CIB/NCCL, Baghdad, Iraq, 7-9 October 1986; pp. 1-22.

39. Ataie, F.F.; Riding, K.A. Thermochemical pretreatments for agricultural residue ash production for concrete. J. Mater. Civ. Eng. 2013, 25, 1703-1711. [CrossRef]

40. Qudoos, A.; Kim, H.G.; Rehman, A.; Ryou, J.S. Effect of mechanical processing on the pozzolanic efficiency and the microstructure development of wheat straw ash blended cement composites. Constr. Build. Mater. 2018, 193, 481-490. [CrossRef]

41. Biricik, H.; Akoz, F.; Turker, F.; Berktay, I. Resistance to magnesium sulfate and sodium sulfate attack of mortars containing wheat straw ash. Cem. Concr. Res. 2000, 30, 1189-1197. [CrossRef]

42. Binici, H.; Yucegok, F.; Aksogan, O.; Kaplan, H. Effect of corncob, wheat straw, and plane leaf ashes as mineral admixtures on concrete durability. J. Mater. Civ. Eng. 2008, 20, 478-483. [CrossRef]

43. Al-Akhras, N.M. Durability of wheat straw ash concrete exposed to freeze thaw damage. Proc. Inst. Civ. Eng. Constr. Mater. 2011, 164, 79-86. [CrossRef] 
44. Al-Akhras, N.M. Durability of wheat straw ash concrete to alkali-silica reaction. Proc. Inst. Civ. Eng. Constr. Mater. 2013, 166, 65-70. [CrossRef]

45. Bye, G. Portland Cement Composition, Production and Properties; Thomas Telford Limited: London, UK, 1999.

46. Day, R.L.; Marsh, B.K. Measurement of porosity in blended cement pastes. Cem. Concr. Res. 1988, 18, 63-73. [CrossRef]

47. Matusinovic, T.; Sipusic, J.; Vrbos, N. Porosity-strength relation in calcium aluminate cement pastes. Cem. Concr. Res. 2003, 33, 1801-1806. [CrossRef]

48. Papayianni, I.; Stefanidou, M. Strength-porosity relationships in lime-pozzolan mortars. Constr. Build. Mater. 2006, 20, 700-705. [CrossRef]

49. Chindaprasirt, P.; Rukzon, S. Strength, porosity and corrosion resistance of ternary blend Portland cement, rice husk ash and fly ash mortar. Constr. Build. Mater. 2008, 22, 1601-1606. [CrossRef]

50. Standard Test Methods for Sampling and Testing Fly Ash or Natural Pozzolans for Use in Portland-Cement Concrete; ASTM C311/C311M-16; ASTM International: West Conshohocken, PA, USA, 2016.

51. Keattch, C.J.; Dollimore, D. Introduction to Thermogravimetry; Heydon: London, UK, 1975; Volume 45.

52. Shaikh, F.U.; Supit, S.W. Compressive strength and durability properties of high volume fly ash (HVFA) concretes containing ultrafine fly ash (UFFA). Constr. Build. Mater. 2015, 82, 192-205. [CrossRef]

53. Rostami, V.; Shao, Y.; Boyd, A.J.; He, Z. Microstructure of cement paste subject to early carbonation curing. Cem. Concr. Res. 2012, 42, 186-193. [CrossRef]

54. Chindaprasirt, P.; Jaturapitakkul, C.; Sinsiri, T. Effect of fly ash fineness on microstructure of blended cement paste. Constr. Build. Mater. 2007, 21, 1534-1541. [CrossRef]

55. Mindess, S.; Young, J.F.; Darwin, D. Concrete, 2nd ed.; Prentice-Hall: Upper Saddle River, NJ, USA, 2003.

56. Perraki, T.; Kakali, G.; Kontoleon, F. The effect of natural zeolites on the early hydration of Portland cement. Microporous Mesoporous Mater. 2003, 61, 205-212. [CrossRef]

(C) 2019 by the authors. Licensee MDPI, Basel, Switzerland. This article is an open access article distributed under the terms and conditions of the Creative Commons Attribution (CC BY) license (http://creativecommons.org/licenses/by/4.0/). 